\title{
Memoria subversiva, memoria subyugante. Presentación de Jesús de Nazaret*
}

\author{
José Ignacio González Faus, \\ San Cugat del Vallés, Barcelona, \\ Centro de Reflexión Teológica, \\ San Salvador.
}

Nació en una pequeña aldea, hijo de una mujer del campo.

Creció en otra aldea donde trabajó como carpintero hasta que tuvo 30 años.

Después, y durante tres años, fue predicador ambulante.

Nunca escribió un libro. Nunca tuvo un cargo público.

Nunca tuvo familia o casa. Nunca fue a la universidad.

Nunca viajó a más de trescientos kilómetros de su lugar de nacimiento.

Nunca hizo nada de lo que se asocia con grandeza.

No tenía más credenciales que él mismo.

Tenía sólo treinta y tres años cuando la opinión pública se volvió en su contra.

Sus amigos le abandonaron.

Fue entregado a sus enemigos, e hicieron moła de él en un juicio.

Fue crucificado entre dos ladrones.

Mientras agonizaba preguntando a Dios por qué le había abandonado, sus verdugos se jugaron sus vestiduras, la única posesión que tenía.

Cuando murió fue enterrado en una tumba prestada por un amigo.

Han pasado veinte siglos, y hoy es figura central de nuestro mundo, factor decisivo del progreso de la humanidad.

Ninguno de los ejércitos que marcharon, ninguna de las armadas que navegaron, ninguno de los parlamentos que se reunieron, ninguno de los reyes que reinaron, ni todos ellos juntos, han cambiado tanto la vida del hombre en la ticra como esta Vida solitaria.

* Publicado por Centre d'estudis Crisrianisme i Justicia. Barcelona, abril. 2001. 
Este poema anónimo, al que he añadido la frase en letra cursiva, describe perfectamente lo que constituye el asombro y la dialéctica del hombre Jesús de Nazaret, nacido y ejecutado en Palestina hace unos dos mil años. La misma dialéctica que expresa el título de este artículo calificando su recuerdo como subversivo y subyugante. Ambos adjetivos son sólo una traducción moderna de otro juego de palabras, tomado de una frase brblica que se aplicó varias veces a Jesús: la piedra desechada por los constructores se ha convertido en piedra angular del edificio'.

Esa dialéctica recubre a su vez toda la vida de Jesús, la cual puede ser calificada como "un debate sobre Dios". Debate mantenido con los representantes "oficiales" de Dios, en el que Jesús termina siendo acusado y condenado como blasfemo, para más tarde ser confesado como "Palabra" e "Hijo Único" de Dios.

Esa blasfemia consistió en anunciar, poner en práctica y hacer presente a un Dios que no era el dios de los poderes religioso o político, sino el Dios de los excluidos o marginados por esos poderes. De esta manera, aquel hombre anónimo, que no fue doctor, ni tuvo cargos, ni escribió libros, acabó realizando la mayor revolución espiritual de la historia humana: dejó sentado que el camino hacia Dios no pasa por el poder, ni por el templo, ni por el sacerdocio, ni por la ley, ni siquiera por la estética (a la que Jesús, por otra parte, era bien sensible), sino por los excluidos de la historia. Una revolución tal que quizá sea inasimilable para nosotros. Pero que "ahí está", para nosotros también.

Este artículo intenta presentar someramente a ese personaje tan conocido y tan desconocido. Tarea diffcil, pues de ningún otro individuo humano se han ocupado tanto los hombres a lo largo de la historia. Y esa infinita literatura ha dado lugar, inevitablemente, a una auténtica "babel" de teorías y de explicaciones las cuales, muchas veces, no estuvieron exentas de aquello que profetizaba el viejo Simeón: este niño va a "poner al descubierto muchos corazones" (ver Lc 2, 35).

Es imposible en este artículo adentrarse en esa babel. Por eso será mejor comenzarlo preguntando simplemente a varios de los primeros testigos, lo que fue Jesús para cada uno de ellos. Conviene que sean varios, por si nos sorprende la pluralidad de las respuestas. Pero quizá eso signifique que cada una tiene algo que decir y que ninguna puede decirlo todo.

1. La frase del Salmo 117 se aplica a Jesús en los evangelios sinóplicos (cfr. vg. Mc 12. 10), en los Hechos $(4,11)$, y en IPedro 2, 4 y 7 . Parcialmente también en Efesios 2. 20. Junto al Salmo 109 y los poemas del Siervo de Isaías. es uno de los textos del Antiguo Testamento más aplicados a Jesús. 


\section{Introducción: cuatro testigos}

\section{Pablo: liberación de la libertad}

Comienzo por Pablo porque, al igual que nosotros, no fue testigo inmediato de la vida de Jesús, sino sólo de su resurrección. Aquel fanático perseguidor de los cristianos, que acabó siendo uno de ellos y liderando a muchos de ellos, vivió obsesionado por comunicar su experiencia de Jesús, que él resume así: la "verdad del evangelio" es "la libertad que tenemos en Jesús el Mesías" (ver Gal $1,5$ y 1,4$)$. Y esa libertad consiste en que "en Jesús el Mesías ya no hay judío o pagano, mujer o varón, libre o esclavo" (Gal 3.28). Mensaje de una radicalidad tal que ni veinte siglos de cristianismo han logrado darle realidad suficiente.

Esa libertad proviene de que el hombre ya no tiene que ganarse a Dios (ni reconciliarse con su propio superego) a base de su honorabilidad moral. Pues "el Mesías nos rescató de la maldición de la moral" (Gal 3, 13), sin arrojarnos por eso a la esclavitud del deseo. Ello se debe a que en todo el acontecimiento de Jesús se ha revelado el amor incondicional de Dios a cada ser humano y su estar decididamente de parte del hombre.

Ese amor incondicional devuelve al ser humano una dignidad y una tranquila fe en sí mismo, que Pablo expresa con la palabra tan jesuánica de "filiación": Cristo vino para hacernos hijos y su Espíritu clama en nosotros "Abbá" (Padre) (ver Gal 4, 5.6). Aludiendo a situaciones conocidas de su época, Pablo matiza que esa libertad filial: a) es la de hijo de la verdadera esposa y no de la esclava concubina; b) es la dignidad del hijo adulto, ya no menor de edad; y c) es plural: y Pablo podrá definirla como la libertad gloriosa de los hermanos (ver Rom 8 , 21 y Gal 5, 13).

De este modo, "El Mesías nos liberó para que vivamos en libertad" $(5,1)$ sin que esa libertad tenga nada que ver con la autofijación en sí, la cual sería otra esclavitud (Pablo la llama "carne"). Así, las obras que antes exigía la moral y otras que van aún más allá brotarán para Pablo del interior del ser humano, como respuesta espontánea a esa buena noticia del saberse amado por Dios.

El hecho de que Dios permitiera la muerte en cruz de Jesús antes que acabar con sus asesinos ${ }^{2}, y$ de que Jesús actuara igual (sin recurrir a Dios para escapar de sus verdugos) revela hasta qué punto Dios y Jesús están de parte de los hombres. Por eso, Pablo dirá provocativamente que no quiere presumir de nada más que de la cruz de Cristo $(\mathrm{Gal} 6,14)$ y que a él no le interesa saber otra cosa que "a Jesucristo y éste crucificado" (1Cor 2, 2). Pero el temperamento pasional de Pablo sabe que al hablar así es parcial, pues en esta misma carta propone la enseñanza más importante sobre la resurrección, de todo el Nuevo Testamento

2. Lo "entregara" dice Pablo; o "no le perdonara ni a El". Ver Romanos 8, 32. 
(1Cor 15). Y en la anterior reconoce también que cuando "las cabezas de los apóstoles" ratificaron su evangelio de libertad, le recomendaron que no por eso "se olvidara de los pobres" (Gal 2, 10), cosa que él confiesa haber cumplido con esmero. Aquí tenemos la posibilidad de pasar a un testigo nuevo.

\section{Santiago: los pobres señores del reino (Sant 2,5 )}

Santiago, "el hermano del Señor", que no había creído en él durante su vida, fue testigo de una aparición del resucitado, y acabó creyendo en Jesús, y siendo líder de la comunidad cristiana de Jerusalén. Según parece, tuvo dificultades para integrar su fe en Jesús con su antigua religiosidad judía. Pero estas mismas dificultades, le sirvieron para subrayar, en su experiencia de Jesucristo, lo más válido y definitivo de la tradición del Antiguo Testamento: la identidad entre Dios y la justicia.

En efecto, tras su encuentro con Jesús, Santiago escribe que "la fe en el Señor glorificado" no es compatible con un trato mejor a ricos que a pobres, en el interior de la comunidad, porque eso sería "blasfemar del hermoso Nombre que invocamos", ya que los pobres son "elegidos de Dios y herederos del reino" (ver 2, 1-7). Si esto vale al interior de la comunidad cristiana, le permitirá recobrar, para la sociedad civil, las diatribas de los profetas contra los ricos. Esos que viven diciendo: "iremos a tal ciudad, negociaremos allí y ganaremos dinero" han de saber que "el salario no pagado a los obreros, clama al cielo... y llega a los oídos del Señor"; que ellos no hacen más que "matar al Justo que no se resiste", pero que algún día se encontrarán con la venida del Señor (ver 4, 13$5,8)$. Estos son prácticamente los únicos pasajes con alusiones "al Señor Jesucristo" $(1,1)$, en esta carta llena de normas de conducta. Pero ellos le permiten remontarse hasta la esencia cristiana de la religiosidad: "la verdadera religión ante Dios consiste en atender a los excluidos e indefensos y no dejarse contaminar por los criterios de este mundo" $(1,27)^{3}$.

Ya desde Lutero, la teología creyó encontrar contradicción entre el moralismo de esta carta y la libertad de la fe paulina. Esta contraposición se atenúa mucho si atendemos al ejemplo expreso con el que Santiago critica la fe sin obras $(2,15-16)$ : ésta sería como ver a un hermano hambriento y pasando frío, y limitarse a decirle: "abrlgate y come bien", sin ayudarle en nada. Es decir, una libertad sin solidaridad es una burla de la libertad. Cosa que Pablo también acepta.

3. La carta habla de "huérfanos y viudas" que, en la sociedad del Antiguo Testamento. son el paradigma de la exclusión, por su total carencia de medios. En cuanto a "los criterios de este mundo", parecen ser los que se censuran a continuación para que no entren en la comunidad cristiana: "tratar mejor al rico y menospreciar y oprimir al pobre". 
Curiosamente, este lenguaje recuerda mucho al del evangelio de Lucas (ique cra griego y discípulo de Pablo!), en su dureza contra los ricos y su bienaventuranza para los pobres. Ello puede mostrar que. aunque cada testigo ha procesado a su modo la experiencia de Jesús, se dan entre ellos concomitancias y transierencias, por su relerencia a la misma fuente (véase también lo que diremos de san Mateo, en el capítulo 2, apartado 3.1.).

\section{Juan: el fin de la religión}

Los escritos Ilamados joánicos no son de un único autor, sino de loda una comunidad, y han atravesado diversas fases en su redacción. En esta comunidad parece haberse dado la experiencia más intensa de Jesús. Ningún escrito del Nuevo Testamento habla tan intensamente de Jesús. Pero, al hablar de Jesús, se habla de Dios y del amor a los hombres. El que no conoce al Hijo no conoce al Padre (IJn 2, 23; Jn 14, 9 ). Pero al Hijo se le conoce "guardando su inandamiento" (ver 15, 10). Este mandamiento es el "ámense los unos a los otros". Aunque parece un mandamiento viejo (de hecho está presente en todas las religiones), para el seguidor de Jesús es un mandamiento "nuevo" ( $1 J n$ 2, 7), porque Jesús lo ha convertido en experiencia de Dios. Por eso, si nos amamos "hemos pasado de la muerle a la vida y hemos conocido a Dios" ( IJn 3, 14 y 4, 7). Mientras que si alguicn dice que ama a Dios (;a quien no ve!) y no ama a su hermano (a quien ve $y$, a veces, experimenta como bien poco amable) es un embustero ( $1 \mathrm{Jn} 4,20)$. De ahí que la experiencia de Dios hecha a través de Jesús por esta comunidad, quedara resumida en la frase "Dios es amor", que no debe ser separada de la otra: "Dios es Luz" (IJn 4, 7 y I, 5).

Advirtamos que no se puede reducir este evangelio a la frase de Jesús: "El Padre y yo somos uno", si no se le añade el mandamiento del amor. Porque la primera frase está dicha probablemente para marcar la diferencia entre Jesús y nosolros y la exclusividad de Cristo. Reducirla a una experiencia mística común, en la que luego se puede incorporar todo, tiene el peligro de incorporarlo todo menos las víctimas, que no suelen caber en esas experiencias. La comunidad de Juan avisa expresamente contra esto: "si alguien que posee bienes de la tierra ve a su hermano en necesidad y le cierra el corazón, el amor de Dios no está en él" $(3,17)$.

Y añadamos que es precisamente la experiencia del amor, la que deja abierlas la vida y la verdad cristianas a una gran creatividad; pues el amor (que es el Espíritu de Dios) ha de enseñar aún muchas cosas e ir conduciendo hacia la plenitud inalcanzable de la verdad. Curiosamente. la comunidad que más parece haber amado a Jesús (iy al Jesús venido "en la carne"!), es la que queda menos alada a una mera mimética del Jesús histórico, por su seguridad en el don de Jcsús. que es El Espíritu. 


\section{Pedro: la no violencia de Dios}

El autor de la Primera Carta de Pedro parece proyectar sobre los destinalarios su propia experiencia de Jcsús, cuando les dice que "han gustado cuán hucno es el Señor" $(2,3)$ y que, por eso, lo aman y creen cn Él sin haberlo conocido $(1,8)$. Pero quiere advertirles que esa bondad que aman convierte a Dios en débil y piedra de tropiezo en estc mundo. como la piedra rechazada por los constructores (2,6-7). Y quiere que este recuerdo capacite a sus leclores para soportar el "ser rechazados por el nombre de Cristo" o "sufrir por ser cristianos" (4, 14 y 16): porque así seguirán las huellas de Jesús, que no cometió pecado. ni encontraron engaño en su boca, que al ser insultado no devolvía los insultos, ni respondía al maltrato con amenazas, y cuyas heridas nos han curado porque, al morir por nucstros pecados, nos abrió el camino para morir nosotros a nuestros pecados y vivir para la justicia $(2,22-24)$.

No sabemos si es Pedro el autor de esta carta, que parece transida de alusiones a la figura isaiana del Siervo de Yahvé. Pero se comprende que se la haya puesto bajo su nombre, para evocar tanto la conlliclividad cristiana como el recuerdo de aquel que, ante esa con lictividad, había respondido con la espada y había acabado negando al Señor. para verse regenerado por su perdón. En cualquier caso, el autor de la carla busca que esta actitud no violenta marque no sólo las relaciones sociales del cristiano $(2,10 \mathrm{ss})$, o sus relaciones familiares $(3$, Iss) y eclesiales $(5,1 s s)$, sino también su respuesta a la persecución. Porque, al participar en el rechazo de la piedra angular, se participa taıbién en su destino linal. Ello le permite formular que "hombres libres no son los que toman la libertad como un pretexto para la maldad", sino los que "obrando el bien tratan de cerrar la boca a los insensatos" (2, 15 y 16$)$.

\section{Conclusión}

El recuerdo de Jesús en algunos de sus primeros lestigos se revcla como una verdadera sacudida en la religiosidad humana, y un auténtico debate sobre Dios. Jesús parece haber hablado poco sobre Dios. Pero puso en práclica un Dios lundamento de libertad. vindicador de lo excluidos, presentc en el fratcrno amor a los hombres y voluntariamente débil antc el rechazo huınano. En adelante. oplar por Dios habrá de implicar oplar por el hombre. Y optar por el hombre habrá de implicar optar por el pobre. Pero esta triple opción deberá llevarse a la práctica en un marco de no violencia y de respeto a la libertad de los demás. Vale la pena que intentemos acercarnos a ver quién y cómo lue el autor de esa silenciosa revolución religiosa.

\section{Acercamiento a los hechos}

Jesús debió nacer hacia el año 5 anles de nuestra cra. Uno de sus biógra「os, el que asegura haber investigado más minuciosamente, no teme contradecir cl 
género literario de las biografías de grandes personajes, afirmando que nació en una cueva que servía de establo o de pesebre. Vivió de niño en Nazaret y, como era normal, aprendió la profesión de su padre, que hoy situariamos en "el gremio de la construcción".

\section{Esbozo narrativo}

\subsection{Expectativas}

Debió escuchar la predicación de Juan Bautista, puesto que acudió a ser bautizado por él. En esta predicación (o quizá en algún hipotético contacto con los esenios) se fue gestando en él una peculiar experiencia de Dios, que llevaba aneja una particular conciencia de misión. La llamo peculiar porque no cabe en ninguno de los cuatro grupos religioso-políticos ${ }^{4}$ que dividían la sociedad en que vivió: ni en la aristocracia saducea, ni en los observantes fariseos, ni en los "monjes" esenios. ni en lo que entonces sería el germen de los revolucionarios "zelotes", que aún no existían como movimiento organizado, pero sí como sensibilidad ambiental. A lo más cabría decir que Jesús anduvo más cercano a esıos dos últimos. de los cuales también se separó; del tercero por su negativa a despreciar a las masas y a considerarse del grupo de los "santos y puros". Y del cuarto, por su rechazo de la violencia terrorista como medio liberador.

Del imperio romano, parece que lo que más irritaba a Jesús era la colaboración de la aristocracia sacerdotal (saduceos) con él, aún más que la misma dominación romanas.

Finalmente, otro rasgo de marginalidad en aquella sociedad nos to da el hecho de que Jesús nunca se casó.

Hacia los 28 años, y como fruto de la experiencia dicha, comenzó a recorrer los poblados de Galilea. Judea, Samaría y la Decápolis, anunciando la inminencia de una intervención divina en la historia, a la que él llamaba "reinado de Dios". También parece cierto que en ese recorrido, Jesús cludía (¿deliberadainente') las grandes ciudades.

Esa actividad parece haber estado marcada por algún "gesto inaugural". En pritner lugar, el bautismo por Juan, como un pecador más, y con un tipo de experiencia "Filial", que confirmó su conciencia de misión. Pero quizá también algún discurso como el que cuenta Lucas 4 al comienzo del minislerio de Jesús, en la sinagoga de Nazarel, cuando Jesús lee el Capílulo 61 de Isaías (suprimien-

4. La scparación de ambas palabras era entonces imposible.

5. Aunque no se puede excluir que los evangclisıs dulcilicaran la oposición de Jesús a los romanos, porque se escriben para ser dilundidos en el imperio. Como hicicron. sin duda, con la figura de Pilato. 
do quizá la frase que habla de venganza), y comenta que aquello "se está cumpliendo hoy ante ustedes", provocando un primer conflicto serio.

Su praxis no era sólo verbal. Iba acompañada por una serie de gestos "Ilamalivos": curaciones, contactos y acogida de gente "impura", y comidas con los excluidos sociales. En cualquier caso, su actividad desata inmediatamente un éxito clamoroso en las masas, y una reticencia creciente en los ambientes "eclesiásticos". Los evangelios merecen crédito cuando describen a Jesús envuelto por "masas", "turbas", "multitudes", y cuando cuentan que esas masas se maravillaban del "poder de libertad" (eksousía) de sus palabras, que no eran como las de los escribas y fariseos. El comienzo de Marcos recoge, a la vez, ese éxito clamoroso, y una serie de conductas "sospechosas": en sólo dos capítulos Jesús toca a un leproso (es decir, contrae impureza), llama a un publicano, quebranta dos veces el sábado y se atribuye el poder divino de perdonar pecados. Es casi normal que semejante arranque llevase a un veredicto negativo por parte de los "bienpensantes" (ver Mc 3,6).

En esta situación tan contrastada, parece también históricamente cierto que Jesús rechazó la vía del poder, que algún evangelista describe como un intento de "proclamarlo rey".

\subsection{Crisis}

Hacia la mitad de su vida pública, se produce una crisis importante: sus discípulos reciben con frecuencia el reproche de no entender. El pueblo aparece también como desconcertado (y un evangelista pone en labios de Jesús este duro reproche: "ustedes me buscan no porque han entendido mis signos, sino porque comieron hasta saciarse"). Los (ariseos le exigen una prueba irrefutable que Jesús se niega a dar. La crisis lo llevó a poner a sus discípulos en una siluación de decisión. Parece cierto que fue gracias a una confesión impulsiva y generosa de Pedro, como los discípulos fueron resolviendo su desconcierton. Ellos y el pueblo seguirán tras él, pero mucho más atraldos por la fuerza de su irradiación, que por haberle comprendido plenamente.

La segunda parte de su camino, parece haber estado marcada por un horizonte más nublado. Aunque la crisis no altera las "entrañas conmovidas" de Jesús, que cran el motor de toda su actividad, sí que se nota una búsqueda de caminos nuevos: menos apariciones en público, más dedicación a sus discípulos, y algunos períndos de refugio en el extranjero?. El testimonio de los evangelios parece

6. "Tú eres el Mesías" en la narración sinóptica. "Sólo tú tienes palabras de vida elerna" en el cuarto evangelio.

7. El hablar en parábolas no parece fruto de este "cambio de táctica", pues es cronológicamente anterior a la crisis. Forma parte del estilo colorista de Jesús. 
también creible cuando, en esta segunda milad, cuentan muchas menos curaciones y actos "milagrosos" de Jesús.

\subsection{Desenlace}

La confrontación sigue hasta que Jesús se decide a afrontarla subiendo a Jerusalén, para llevarla hasta el centro mismo de su fe judía. La estancia en Jerusalén tiene un esquema semejante al de la vida anterior: éxito clamoroso a la llegada (con el consiguiente miedo de los dirigentes religiosos), días de controversia en el atrio del templo, unas palabras estremecidas de Jesús sobre Jerusalén, en las cuales definió a la capital religiosa como aquella que "mata a los profetas y apedrea a los que le son enviados por Dios" y, por último, la decisión de los sumos sacerdotes de acelerar la "solución final". Según la cronología de los evangelios, menos de una semana en Jerusalén, y entre uno o dos años de actividad en Palestina. Hasta ese punto resultó molesto.

El empeño biográfico permite decir poco más. Pero, en contra de lo que suele pensarse, eso no es sólo una desgracia. Es también expresión de una cierta anonimidad pretendida. Uno de los más antiguos himnos creyentes en Jesús, proclama que su "condición divina" no fue obstáculo para que se presentara "como uno de tantos y acluando como un hombre cualquiera" (Fil 2, 7ss). Una presentación de Jesús fracasaría si el lector no llega a imaginarlo como uno más: entre los pecadores que se acercaban al bautismo de Juan, caminando por las callejas como un hombre cualquiera, sin ningún tipo de carroza o "jesusmóvil" que lo distinguiera de las gentes, vestido como los galileos de su época, usando los baños y piscinas públicas con la posibilidad de acercarse a quienes allí cstán (ver Jn 5, 2ss) y sin necesidad de construirse sus propias instalaciones exclusivas, tratando precisamente con aquellos con quienes nosotros no solemos tratar, y no con aquellos otros con quienes suelen codearse los grandes y los jefes de este mundo. La precariedad de su biografía es expresión de esa anonimidad, que es lactor esencial de su teología.

\section{La actividad de Jesús}

No obstante, sí que es posible extraer del marco anterior algunas de las tormas concretas de su actividad. En ese bienio escaso Jesús:

a) Comunicó y anunció (mejor que enseñar) lo que es el reino de Dios que llega. A esto remite el asombro que su predicación despertaba (ver Mc I, 22). las bienaventuranzas, las parábolas, etc. Ampliaremos esie punto en el capílulo siguiente.

Pero después. los evangelistas entendieron ese lenguaje como una constatación de la ceguera de los jeles que "viendo no ven y oyendo no oyen". 
b) Compartió mesa, intereses y sentimientos con los excluidos de aquella sociedad (ver Mc 2, 15ss; Lc 15, 1; Mi 11, 25ss).

c) Acogió y curó, entendiendo estas acciones como señales de la llegada del reino (Lc II, 20).

d) Llamó a algunas gentes sencillas para que lo siguieran en el estilo de vida que emprendía". Parece seguro que los envió a anunciar el reino, y que trató de construir con ellos una especie de "comunidad alternativa", que no se rigiera por los criterios de la sociedad civil de aquella época, que Jesús resumía así: "los que gobiernan tiranizan, y encima se hacen llamar bienhechores" (ver Lc 22, 25ss: "entre ustedes no sea asî").

e) Entró en conflicto con la tcología oficial (en temas como el sábado, en qué consiste la pureza del hombre, con quiénes está Dios, cuál es el sentido y valor de la ley...).

t) Entró en conflicto con el templo y el culto oficial, permitiéndose incluso una acción de cierta dureza, al echar por tierra todo el montaje de ventas que posibilitaba el culı, y declarar que aquel templo estaba llamado a desaparecer y ser sustituido por otro "no hecho de manos humanas".

g) Desaló la necesidad de quilarlo de en medio violenta y ejemplarmente. Necesidad que se justificó en nombre de Dios, pero que procedía de la sensación de amenaza que acompañaba a su anuncio del Dios del reino.

h) Cuando ya vio venir el linal, apostó por la esperanza hasta tal punto, que decidió celebrar una cena con los suyos". En ella hizo un gesto simbólico, quc las comunidades cristianas aún repiten: compartió el pan (símbolo de la necesidad humana) y pasó una copa de vino (símbolo de la alegría comunicada), dando a entender que en ese gesto de la necesidad compartida y de la alegría comunicada, se resumía su vida y él se haría presente entre los suyos.

\section{Conclusión}

Cerraremos esta rápida panorámica señalando que de los títulos que la investigación moderna da a Jesús (y que no pretenden ser tílulos creyentes, sino flashes del personaje), los dos más salislaclorios son los que lo califican como "un judío marginal" y como "profela escatológico" o "dcl lin de los tiempos" (quc, repito, no es un título creyente, puesto que no se pronuncia sobre la veraci-

8. Sencillas pero inuy heterogéneas: simples pescadores del lago, algún esenio o discípulo de Juan, un recaudador de impuestos ("publicano"), algunos simpatizantes de lo que luego iba a cuajar como el movimiento zelote...

9. Por razones que aquí no caben. Ia crílica hisıórica parece preferir la cronología de Juan sobre la cena. a la de los sinóplicos. Aquél no la considera como cena pascual. Esıos sí. 
dad de ese proleta). Estas instantáneas me parecen preferibles a otros títulos (un sabio, un santo, un revolucionario, un itinerante similar a los cínicos griegos...).

Quizá, a estos dos lítulos elegidos, habría que añadir el de (hijo de) El Hombre: porque parece muy probable que es así como Jesús se designó a sí mismo, y porque entraña una ambigüedad muy del gusto de Jesús: puede aludir a "un hombre cualquiera" ( $c f r$. Fil 2), pero alude también a la plenitud utópica del ser humano (por eso lo escribo con mayúsculas). Todo esto se verá con más claridad si ampliamos un poco esas instantáneas en el capítulo siguiente.

\section{El personaje: marginal, profeta, humano}

Lo que constituye a un ser humano es su conciencia humana. Pero a esta conciencia no podemos tener acceso inmediato. Sólo nos acercamos a ella a través de sus palabras, de su prácticas y de su estilo, sobre todo cuando son habituales.

Pero, dado que la noción antigua de historiografía no era exactamente la nuestra, el criterio para acceder al personaje no son textos aislados (aunque unos pocos tengan garantías muy serias), sino más bien la confluencia de textos que trazan un rasgo, aun cuando uno u otro de ellos pueda ser de historicidad discutible. Buscaremos el acceso a Jesús a través de los siguientes trazos.

\section{1. "Abba" y reino}

Hay dos palabras de las que ningún crílico discute que fueron repetidas por Jesús con notable frecuencia: la invocación a Dios como Abbá (Padre) y la irrupción cercana del reinado de ese Dios. Jesús invitaba a los suyos a llamar también a Dios $A b b a ́$. Pero lo que significa esa paternidad, sólo podemos entenderlo a través de lo que entendía Jesús como el reinado de Dios. He aquí algunas vías de acceso a ese "reino", que revela a Dios.

\subsection{Testimonios ambientales}

En primer lugar, la descripción que hace el Salmo 145. Alli se enumera una situación humana de libertad. justicia, superación de la enfermedad y de la carencia, bondad y acogida del débil. Cuando esto ocurre, "Dios reina".

Hay, además, dos textos útiles en los evangelios apócrifos: "el reino del Padre está extendido sobre la tierra y los hombres no lo ven" (evangelio de Tomás 113). Y este otro: "Quien conozca a Dios se encontrará el reino, porque conociéndole a él se conocerán a ustedes mismos y entenderán que son hijos del Padre. Y a la vez sabrán que son ciudadanos del cielo. Ustedes son la ciudad de Dios" (Pap Oxyr. 654) ${ }^{10}$. Dos textos muy ricos, cuyas palabras subrayadas dan para meditar un momento.

10. Papiro encontrado en Egipto, en 1897. A juzgar por otros Tragmentos de ese mismo 
Elijo cslas cilus no porque tengan más garantía de historicidad (dadas sus luentes. no es posible alimarlo), sino porque resumen muy bien la enseñanza de los evangelios sobre el reino. Podemos añadirles estas otras dos citas de Pablo: "el reino de Dios no es comida ni bebida, sino justicia y paz y gozo en el Espíritu Santo" (Rom 14, 17), es decir, igualdad entre los hombres, reconciliación con uno mismo y referencia de todo eso a la gratuidad. $\mathrm{Y}$ "el reino de Dios no viene por las palabras, sino por su propia fuerza" (ICor 4, 20), en la línea del evangelio de Tomás, antes citado.

\subsection{La praxis de Jesús}

En segundo lugar, el mismo Jesús parece haber interpretado su tarea curativa como una "señal de que el reino de Dios está llegando", y no como una demosIración de poder sobrenatural, que garantice su divinidad. Esta última interpretación. aunque parece más tradicional, procede de nuestra modernidad. Los Tariseos no cuestionaban ni las curaciones de Jesús ni su carácter "extraño". Por eso. buscan más bien atribuirlas a artes mágicas o al demonio. Y ello dio ocasión a que Jesús explicara como las entendía él (ver Lc 11, 20).

\subsection{Sus parábolas}

En tercer lugar destaquemos dos rasgos de las parábolas:

a) el reino de Dios se parece a un tesoro escondido. Quien lo descubra tendrá tanta alegría que dará gustoso por él todo lo que tiene (Mt 13,44ss): es como una semilla que, bien cuidada, va creciendo por si sola, aunque el labrador duerma (Mc 4, 26ss). Y sin embargo,

b) vuelve a aparecer aquí la conflictividad: en ese reino no entran las gentes "morales" (fariseos y escribas), sino los excluidos por su inmoralidad ("publicanos y prostitutas"). Pues la moralidad del (des)orden establecido es una moralidad insolidaria que, al excluir, fuerza a muchas gentes a esas conductas inmorales.

Pongamos un único ejemplo de ello en la parábola de los que asisten al banquetc (Lc 14, 15-22). Los banquetes públicos de los ricachones eran práctica conocida en tiempos de Jesús, y él recurre a ella para visibilizar el reinado de Dios, pero cambiando los comensales. Nosotros entendemos que los que no quisieron asistir fingían excusas.

En realidad puede tratarse de justificaciones válidas. La posibilidad de un buen negocio es una excusa razonable para no asistir a un banquete, entonces y hoy. El haberse casado era tenido lambién como excusa razonable pueslo que,

papiro ya conocidos. el texto cítado podría ser del apocrifo llamado Evangelio de los Hebreos. 
en el mundo de Jesús, los banquetes no eran para mujeres, sino sólo para varones. Y el que está en plena luna de miel se comprende que no pueda renunciar a ella...

En esta parábola (como en otras muchas"), Jesús denuncia que las conductas moralmente plausibles suelen acabar siendo conductas que justifican o enmascaran la insolidaridad con los débiles y excluidos. Mientras que los que no pueden exhibir esas conductas quedan más abiertos a escuchar la llamada de la solidaridad.

Comenzamos a encontrar aquí cómo el anuncio del reino es a la vez, subyugante y subversivo. El anuncio de Jesús sobre el reino de Dios podría retraducirse hoy así: "la revolución de Dios esta ahí. Crean esta buena noticia y cambien de mentalidad" (ver Mc I, 15). El mismo carácter subversivo y subyugante tiene el Dios que ese anuncio revela. La paternidad de Dios no es una broma: no sólo porque se trata de una paternidad de hombres adultos, sino porque es una paternidad de todos ${ }^{12}$.

\section{Una extraña libertad}

La sociedad por la que anduvo Jesús era notablemente cerrada. En cientos de años no se había movido una tilde, ni un ápice, en materia de costumbres. Jesús tampoco parece haber tenido contacto con el judarsmo de la diáspora, más crítico y más ilustrado, por el influjo griego.

Sorprende por eso que, desde los comienzos, y sin renunciar por ello a sus prácticas de judio observante, actúe con una desconcertante libertad, en temas tan serios como la guarda del sábado, los usos sociales de trato con la mujer, las normas de pureza, o el contacto con paganos y samaritanos. $O$ que se maniliestc en contra de lo que él consideraba permisividad de la ley mosaica, en cuestiones como el repudio de la esposa, alegando que Moisés hab́a transigido con la dureza de corazón del hombre, pero que ése no era el plan original de Dios sobre la pareja humana' ${ }^{13}$.

II. Buen samaritano, fariseo y publicano, oveja perdida, hijo pródigo...

12. Para el tema de Dios que ya no cabe aquí, remito a mi capítulo ("Jesús y Dios") en la obra en colaboración Diez palabras sobre Jesús de Nazaret, Estella. 1999. pp. 189- 248.

13. Jesús no habla del divorcio (o separación de común acuerdo ante una situación insostenible, y que no existía en su mundo, dada la inferioridad de la mujer), sino del repudio o "carta de despido" que aquella sociedad machista permitia a los varones, por razones bien mínimas, y que dejaba a la mujer totalmente desvalida. El verbo apollyomai (Mi 5, 32; 19, 3; Mc 10, 2ss; Lc 16. 18) no signilica acción mulua (separarse), sino acción unilateral (soltar). Se trata aquí de una defensa de la mujer y no de una norma de moral conyugal. 


\subsection{Libertad que da autoridad}

Los evangelios califican esta libertad de Jesús con la palabra eksousia. Es una palabra que signilica a la vez autoridad (o poder) y libertad. Y que aparece con ambos significados en el Nuevo Testamento. Por eso, antes la he traducido como "el poder de su libertad". Es el único poder que pretendió tener Jesús. Por cso se comprende el comentario extrañado y repetido (pero no precisamente crítico) con que las gentes comentaban sus palabras: " ¿de donde le viene a éste esa autoridad, si no ha cstudiado con ningún maestro?...". Un rasgo que también parece confirmar el cuarto evangelio: "nadie ha hablado jamás como este hombre" $(7,48)$.

\subsection{Libertad en favor del necesitado}

De toda esta libertad no cabe aquí más que un ejemplo. Elegiremos el del sábado, por lo que significaba en el mundo judío, y por la abundancia de testimonios sobre él, en los evangelios. Jesús quebrantó repetidas veces el sábado, sobre todo para curar, desoyendo el consejo prudente de esperar a otro día de la semana, y alegando que no podía estar prohibido hacer bien en sábado, porque cl día sagrado fue hecho para el hombre y no al revés.

Curiosamente, hoy podemos adivinar que, con esta práctica transgresora, devolvió al sábado su verdadero sentido tcológico. En sus orígenes, el sábado había sido una institución social, no cúltica: perseguía el descanso del asalariado y del esclavo, $y$ lo fundamentaba (como era frecuente en muchas prescripciones del mundo antiguo), declarando "sagrado" el día festivo: en él "había Dios descansado de su creación" (Gen 2, 2). Se podía deducir de ahí que el descanso de Dios es prccisamente el alivio del necesitado. Y por eso, Jesús entiende que dar alivio al enfermo no es quebrantar el sábado, sino cumplir su intención más prolunda: eso es lo que significa que el sábado había sido hecho para el hombre. Y así lo entiende también el cuarto evangelio, cuando le hace decir a Jesús, en contra de la literalidad de la Biblia que "Mi Padre siguc trabajando" (Jn 5, 17), mientras quede un entermo por curar.

La objeción de que sería mejor esperar a otro día de la semana, vislo que no se tralaba de curaciones urgentes, no tuvo fuerza para Jesús, aunque ello significase echar piedras contra su propio tejado, puesto que desautorizaba sus curaciones, precisamente, por estar hechas transgrediendo la ley ("este hombre no viene de Dios porque no guarda el sábado"). Al rechazar este modo de argüir, Jesús parece dejar claro que lo importante de sus curaciones no era el protagonismo del taumaturgo, sino el protagonismo del enfermo.

Finalmente, al atribuir la curación a la fe del enlermo, y no a sus propios poderes, Jesús saca el binomio enfermedad-curación del campo de lo sobrenatural o de lo mágico, y lo devuelve al campo de la creación, que está en manos del 
hombre. De ahí cl comentario de los padres de la Iglesia: Jesús curaba no para quc vićscmos cuínto poder tenía, sino para que sepamos que también nosotros podeinos curar.

\section{Desde los márgenes}

Junto a la eksousia. la otra palabra que los evangelios más usan para calificar a Jesús es la de las "cntrañas conmovidas". Frente a los enfermos, frente a los mil sulrimicntos humanos, liente a algunas situaciones personales, frentc a las multitudes, los evangelios repiten un conocido verbo griego que significa "se le conmovieron las cntrañas"'t. De modo que con el "Abbci", el reino, la autoridad de su libertad, y las entrañas conmovidas, pucde icjerse una rápida tabla impresionista, que echa raíces en lo que con más certeza puede garantizar la crítica histórica.

\subsection{Marginación social...}

Las entrañas conmovidas dan razón de que la vida de Jesús se moviera no en el centro y desde cl centro, sino desde la marginalidad, desde todos esos núcleos y personas que el afán de afimmación individual va arrojando a las cunetas de la historia. Es muy de liar el texto en que Jesús declara que no se siente enviado más que "a las ovejas perdidas de la casa de Israel" (MI 15,24). Y, probableinente. no debemos buscar en él una pretensión de misión universal ya desde el principio. Sin que ello obste para que luego, la explícita exclusión que hacía la religión judía ante los de fuera, lo llevara a poner mil gestos de acogida hacia los paganos, en los que la Iglesia primitiva encontraría fundamento para ir al mundo entero. Sus entrañas conmovidas pusieron una bomba de largo alcance en el corazón del particularismo judio. Y quizá nos sirvan a nosotros, en momentos en que tanto hablamos de universalismo y de "globalización": los fatuos imperios de esta tierra deberían saber que la globalización no consiste en cerrar las propias puertas e imponer los propios productos o la propia cultura. No puede haber verdadera globalización si no se empieza por "globalizar la propia casa", y por integrar a todas su ovejas perdidas, antes de pretender conquistar mundos y mercados.

Las "entrañas conmovidas" permiten a Mateo superar el problema de la relación entre Antiguo y Nuevo Testamento con una frase del profela Oseas, quc marca la pervivencia del primero, inás allá de todas las rupturas: lo que Dios quiere es "misericordia y no culto" (Mt 9, 13 y 12,7). Y, porque eso es lo que Dios quiere, en el juicio último del hombre ante Dios, valdrá lo que se ha hecho inmedialamente al hermano hambriento o enfermo, pero no lo que se ha querido

14. Además de describir una reacción humana normal. podría haber en ese verbo una alusión a Jeremias 31, 20. 
hacer inmediatamente a Dios ${ }^{13}$. De este modo, la frase antes citada de Santiago sobre la religión verdadera, la reformula Mateo con una frase de Jesús: "si al ir a presentar tu ofrenda al altar, recuerdas que tu hermano tiene algo contra ti, deja el altar y ve a reconciliarte con tu hermano" $(5,22-24)$. Tendría poco sentido disculir si esa frase es palabra literal de Jesús o procede del evangelista, puesto que, en este segundo caso, sería aún más seria para nosolros porque ya no podríamos desautorizarla diciendo que se refiere al culto veterotestamentario. $Y$ dado que cuando los evangelistas modifican palabras de Jesús, suelen más bien suavizarlas, habría que preguntarse qué intensidad debió tener la experiencia de Jesús que Mateo hizo cuajar en semejante frase, a la cual ni siquiera los cristianos hemos sabido dar vigencia en veinte siglos.

\section{2. ... fundamentada religiosamente}

Esa ley de gravedad hacia los márgenes podríamos simbolizarla en un gráfico que consta de dos flechas cruzadas (vertical y horizontal), cuyos extremos señalan cuatro dinámicas de exclusión y de marginación: arriba y abajo, a un lado y a otro: enfermos, pobres, mujeres y extranjeros. En una sociedad que se conficsa fundada por Dios y declara tener a Dios en su centro, esas líneas centrílugas aparecerán como brolando de Dios y sancionadas por Él. Y así ocurría en el Inundo de Jesús.

- Pecadores eran los enfermos, y ello justificaba muchas veces su marginación social, cerrando un círculo vicioso, que dificultaba su curación: "impuros" eran los leprosos y por eso había que apartarse de ellos; y ante el ciego de nacimiento los apóstoles preguntan a Jesús quién había pecado, si él o sus padres, para que estuviera así. Jesús, en cambio, curaba no para mostrar su divinidad, sino la fuerza del reino en el ser humano ("tú fe te ha salvado"). La apologética tradicional fue bastante ciega en este punto.

- Pecadores cran también los pobres, "esa masa que no conoce la ley y están bajo maldición" (Jn 7, 49), porque no tenían tiempo más que para endeudarse, hasta que su misma deuda acababa llevándolos a entregarse como csclavos, o a huir a las montañas, hasta cuajar en el movimiento zelote ${ }^{16}$. Si en las parábolas de Jesús aparecen banqueıcs y deudas, no es casualidad, sino reflejo de la condición de su sociedad. Sólo que Jesús invicrte los términos: en el banquete del rcino, los protagonistas son los que nunca habían asistido a una de las comilonas saduccas. $Y$ las deudas son perdonadas, salvo a aquellos que no perdonen a su vez a sus deudores.

15. Comparense Maleo 7. 22-23 o Lucas 13. 26-27 con Mateo 25, 31 ss.

16. El cual, en contra de la presentación habitual, no lue sólo un movimiento contra el imperio exterior pagano. sino también contra la injusticia interior. religiosa. La primera acción de los zelotes, en su ofensiva del año 66, fue quemar lodos los archivos de deudas existentes en Jerusalén. 
- Pecadores eran los extranjeros y los paganos, de los que ya hablamos en el capítulo anterior. Pero aquel judío piadoso no tenía reparo en acudir a casa de un pagano que sufría". Y él, que tanto valoraba la fe y tantas veces reprocha a los suyos su "poca fe", sólo en dos pasajes de los evangelios alaba públicamente la fe de alguien. $\mathrm{Y}$ las dos veces se trata de paganos (el centurión romano y la mujer sirofenicia).

- Y si no pecadoras, inferiores eran las mujeres, tanto en la sociedad griega como en la judía, incapacitadas en ésta para ser testigos y para aprender la ley. Este punto merece mayor explicación, porque hoy es muy difícil que podamos percibir lo subversivo de la conducta de Jesús.

Aparte de algunos trazos ya citados, resultaba extraño verle caminar al lado de ellas, en una sociedad en la que hasta la esposa debía caminar detrás de su marido, cuando ambos salían a la calle. Quienquiera que sea, era un buen conocedor del mundo judio aquel que escribió que (hasta sus apóstoles) "quedaron sorprendidos de verle hablar con una mujer", en público (Jn 4, 27). Así caminó el Galileo: enseñando la ley de Dios también a mujeres y aclarando que también para ellas, ésta era "la mejor parte" (Le 10,24). O entablando con varias de ellas una relación de profunda amistad igualitaria, más llamativa en aquel que enseñaba que la entrega al reino y la pasión por él, pueden llegar a "incapacitar" a algunos seres humanos para una relación conyugal normal, y que "el que pueda, que entienda eso" (ver Mt 19, 12).

Junto a las mujeres. hoy convendría decir otra palabra sobre los otros scres "in [eriores" de aquella sociedad: los niños. Las palabras de Jesús sobre "recibir el rcino como niños" o "hacerse como niños para entrar en el reino", no deberíamos entenderlas desde los rostros infantiles, sonrientes y encantadores, que pueblan tantos espacios de nuestra vida social. Están mejor contextuadas entre los meninos da rua brasileños o los niños que trabajan. "Hacerse como ellos" signilica situarse en los márgenes sociales para poder acceder al reino. Añadiendo el otro rasgo típico de la infancia: el niño sabe (y lo saben aún mejor los ejemplos que hemos citado) que todo lo que tiene es recibido. Gratuidad y marginalidad no se oponían en la mente de Jesús.

Ahí, en los márgenes, encontró a Dios aquel judío marginal y libre. Eso lo hizo exultar de alegría y bendecir a Dios (ver Mi 11, 25ss). Desde ellos lo proclamó, y desde ellos invitó a lodos a preparar su reino. Por eso, muchos no pudieron entenderlo. Y por eso (como veremos), murió "fuera de las puertas de la ciudad" (Heb 13, 12).

17. Los sacerdotes y fariseos no entran en el atrio del pagano Pilato "para no contaminarse" (Jn 18, 28). Jesús decide ir a casa del centurión romano quien, conociendo ya la mentalidad judía, le pide sólo un favor a distancia. 


\section{Una extraña dialéctica ante el ser humano}

Es dato conocido y lamentado, que los evangelios dan muy pocas pinceladas sobre lo que pasaba en el interior de Jesús. Por eso merecen atención estas duras palabras de un evangelista: "muchos creyeron en él, pero Jesús no se fiaba de ellos... Ni tenía necesidad de que se le informara acerca de los hombres, pues él conocía lo que hay en el hombre" (Jn 2, 23-25). Sorprende entonces que este hombre desconfiado sea precisamente el que más ha exigido y esperado de los seres humanos. Es probable que la expresión "los haré pescadores de hombres". que es el único programa que presenta a sus seguidores cuando los llama, no tenga un sentido numérico de proselitismo, sino el de sacar la mejor calidad humana de esa mar turbia de inhumanidad que solemos ser los humanos. Sacar "la mejor versión posible" de cada persona, en línea con lo que habían anunciado los profetas: "cambiar el corazón de piedra en un corazón de carne", o sacar ese ser humano libre y con las entrañas conmovidas al cual cabría calificar como "hombre del reino", en correspondencia con el reino de Dios, anunciado por Jesús.

Jesús era consciente de que muchas conductas moral o religiosamente colreclas no hacen más que enmascarar autocomplacencia, dureza y lalta de solidaridad, afán de ser vistos. Creía que los hombres tienen una medida muy distinta cuando se trata de juzgar a los demás (donde no dejan escapar ni una paja) y de juzgarse a sí mismos (donde son incapaces de ver auténticas vigas), sabía que con frecuencia los más ciegos se erigen en guías de ciegos, contaba con que los seres humanos pueden matar "pensando que hacen un servicio a Dios" ( In 16. 3). Y debió usar bastantes veces palabras como "hipócritas o hipocresía" que, en todo el Nuevo Testamento sólo aparecen (y con frecuencia) en labios de Jesús.

Pero de todo este balance, que podría lírmar Maquiavelo, Jesús no extrajo la conclusión del florentino (sacar partido de la miseria humana en provecho propio), sino que pide a los suyos que no teman, "porque el Padre se ha complacido en ustedes". Creo que es posible afirmar sin ninguna clase de apologética que, aunque conoció la traición y la decepción como todo el mundo, ningún ser humano ha sacado tanto de los hombres como Jesús. Realmente parece haber sido un auténtico "pescador de hombres". Pero no hay que entender estas frases en un sentido falsamente "sobrenatural", sino desde aquel encuadre del Nuevo Testamento que describía a Jesús "presentándose como uno de tantos y actuando como un hombre cualquiera" (Fil 2, 7).

A la vez, este hombre aparentemente duro resultaba escandalosamente comprensivo cuando se tralaba. no de lo que él detestaba como hipocresía. sino de la simple debilidad humana (ver Jn 8, Iss). Salvo el calificativo de "zorro". dirigido al tiranuelo de turno, nunca aparece en sus labios un juicio negativo sobre individuos concrelos. Jesús se ensaña con grupos o formas de ser humano, que 
caben en dos apartados: a) aquellos ricos que "como amaban el dinero se reían de él" (Lc 16, 14), a los que Jesús pide ingenuamente poner todo lo que tienen al servicio de los pobres (ver Lc 12,33); y b) esos fariseos a quienes Jesús acusa de lener el corazón no ya duro sino "necrosado" (Mc 3, 5), ciego. En esla ceguera de corazón, que siempre encuentra razones sólo para lo que le conviene, Jesús parece ver la raíz de aquella hipocresía que tantas veces denuncia. Pues ella Irenaba la innegable "capacidad de encuentro", que parece haber tenido aquel hombre, y que hacía que su acogida a los demás resultara para muchos interlocutores fuente de paz consigo mismos, de autoestima, de salud anímica. de expulsión de los propios demonios y señal del perdón de Dios. A esa capacidad de encuentro parece referirse Oscar Wilde cuando escribe que, para Jesús, no existían leyes, sino sólo excepciones. Pero, olra vez, en contraste con las denuncias de ese fondo posesivo e hipócrita del ser humano, aparece la invitación de Jesús a "lener unos ojos limpios" porque, si los ojos son limpios, todo el cuerpo parece volverse transparente e ilumina con su luz (ver Lc II. 34-36). Y así podría seguir nuestra dialéctica. Pero quedan aún capítulos pendientes.

\section{Su estilo}

El texto que abrió este artículo proclamaba que Jesús "no fue a la universidad, ni escribió libro alguno". No obstante se percibe en los evangclios un claro contraste entre la belleza de muchas palabras puestas en labios de Jesús, y el estilo más bien rudo de los evangelistas.

Su lenguaje estaba hecho de observación de detalles, de colorido meridional y de dialéctica. Entran en él la levadura con que amasa una mujer, el tamaño mínimo de algunas semillas, que luego crecen más de lo que parecía posible, o los dos centavos que da de limosna una anciana insignificante, y en los que Jesús se fija más que en los cheques que dan los señores de este mundo: porque en aquellos centavos iba todo el corazón de la anciana: y en los cheques no va más que un expediente para quedarse tranquilo o llamar la atención (ver Mc 12, 4 Iss). Entra lambién ese modo grálico de pintar la hipocresía como "colar el inosquito y tragarse el camello". Y esa doble mano de ser sencillos como las palomas y "largos" como las serpientes, o de "hacer un cosa pero sin olvidar la olra".

Sus trases más profundas no lo eran porque fuesen inacessibles a la gente sencilla, sino porque lienen diversos niveles de lectura, según la prolundidad del oyente. Al revés de la sabiduría griega. él prefería hablar más de las cosas que vemos que de las esencias que no vemos; pero el oycnte se sentía llevado a éstas, a través de aquéllas. Recurrió mucho al género narrativo, probablemente porque tanto a Dios como al sufrimiento (y aunque por razones diversas), no sc puede acceder a través de nociones abstractas, sino sólo a través de la narración. 
Y sus palabras funden con frecuencia el radicalismo ético del lenguaje de los profelas de Israel, con el tono sapiencial del que sabe buscar lo que más le conviene: de modo que la opción por los pobres, la no violencia, el hambre de justicia, la misericordia, la limpieza de corazón, el trabajo por la paz y hasta la persecución, no eran para él duros imperativos del exterior, sino caminos inesperados de felicidad: "dichosos los tales". Este es uno de esos juegos bruscos de luz que hacía que muchas de sus palabras produjeran vértigo. $Y$ ante ese vértigo, él se limitaba a remitir a los hombres al poder de Dios.

Da la sensación de que, hacia el linal de su vida, su lenguaje se endureció algo. Esto tiene que ver con el último punto que vamos a presentar.

\section{Inesperada conflictividad}

El hecho y la intensidad de esa conflictividad ya fueron citados en el capílulo anterior. Para decir una palabra sobre sus contenidos, añadiremos ahora que la figura y la palabra de aquel hombre supusieron una amenaza inesperada para todos los bienestantes de su sociedad, quizá también una decepción para todos los que, a los principios, se habían entusiasmado con él. La reacción y la decisión de acabar con él fueron increíblemente rápidas. Quizá porque nada vuelve al ser humano más agresivo ni más innoble que el pánico. $Y$ aquellos hombres intuyeron pronto que el reino de Dios y el Dios del reino anunciados por Jesús, suponían el fin de sus privilegios.

Por otro lado, había algo en aquel hombre "manso y humilde de corazón", que desataba su agresividad. Y era ver falsificado el nombre de Dios, utilizándolo como razón para no hacer el bien, o sirviéndose del culto a Dios como fundamento de diferencias de trato entre los hombres (entre judío y gentil, entre mujer y varón, entre laicos y sacerdotes). Esta parece haber sido la razón del escándalo que provocó en pleno templo cuando su primera visita a Jerusalén, y después de haber llorado sobre la ciudad como cualquier seguidor suyo debería llorar hoy sobre el Vaticano. La "expulsión de los mercaderes" del templo no fue una mera denuncia de (¿inevitables?) abusos económicos, sino la desautorización de una forma de culto, que consagraba esas diferencias entre las personas. En estos momentos Jesús, literalmente, saltaba. Y no es que, para él, Dios no hiciera diferencias: pero la única parcialidad de Dios era la parcialidad radical hacia los márgenes y sus moradores.

Es un hecho que los evangelios están jalonados por dardos bien agudos, lanzados por Jesús a los "eclesiásticos" de su época, y que los evangelistas quisieron conservar después, para que no se repitieran en la Iglesia cristiana: "Ustedes quebrantan la voluntad de Dios acogiéndose a sus tradiciones... Devoran los recursos de las viudas con la excusa de rezar por ellas... Pagan el diezmo de la menta y el comino, y pasan de aquello que Dios más desea: la justicia y la inisericordia... Malan a los profetas enviados por Dios, y luego presumen de ser 
hijos suyos... Se visten de símbolos religiosos ("fillacterias") como si Dios mirase lo exterior... La casa de mi Padre no es una cueva de ladrones..." (ver en Mateo los capítulos $15,23.6$ y 21 ).

Así, "suelta la crin y la ternura suelta" ( $P$. Casaldáliga), Jesús luchó contra las falsas imágenes humanas de Dios, deformadas por el miedo o por el interés. Por eso quizá tenga razón el japonés E. Susaku, cuando afirma que en Jesús era perceptible un dejo de tristeza. Pues en este mundo, el amor verdadero no puede menos de verse afectado por el peso de una cierta tristeza.

Los evangelios parecen testificar también que, hacia el final de su vida, disminuye el lenguaje del reino, y Jesús echa mano de un género de su época llamado "apocalíptico", que describe o anuncia calamidades, no tanto como un valicinio, sino como una advertencia, y para proclamar que, a pesar de ellas, Dios sigue siendo Señor de la historia. Pero ese lenguaje apocalíptico parece prefigurado en una de las frases más serias (y más olvidadas) de los evangelios, que revela cómo Jesús (a pesar de esa confianza en el hombre que antes veíamos) era plenamente consciente de la conflictividad de su mensaje: el anuncio del reino de Dios no cabe en los envases de este mundo; sería como meter vino nuevo en odres viejos, o poner un remiendo de paño nuevo en un tejido ya viejo y deshilachado (ver Mt 9,16ss). O se alterará el sabor, o se desgarrará el recipiente. Las iglesias cristianas saben bien hasta qué punto su historia oscila entre estos dos extremos: o aguar el legado de muchas reformas, o hacer saltar la estructura en la que habían brotado.

Esa es la fuerza explosiva de aquella imagen de Dios que Jesús había anunciado con otra de sus dialéclicas extrañas, que nosotros no sabemos armonizar pero que, además de resumir lodo este capílulo, explican lo confliclivo y subversivo, pero también lo subyugante e imborrable de su paso por la historia. Por un lado. que "no se puede servir a Dios y a la riqueza" (Mt 6, 24). Así de sencillo, aunque nuestro mundo diga que no. $Y$ por otro lado, que no hay amor posible a Dios si no se arna al hombre (Mt 22, 34ss). No es que ambos amores sean "lo mismo", pero sí que es imposible separarlos. Aunque a las iglesias les cueste entenderlo.

\section{Conclusión}

Si nuestra exposición ha sido válida, quizá se comprenda lo ajustado de estas palabras de J. B. Metz: "Jesús no fue un loco ni un revolucionario; pero se parecía palpablemente al uno y al otro, hasta dar pie a que lo confundieran con ellos. Al final, Herodes lo trató de loco y sus paisanos lo entregaron a la cruz como subversivo. Quien se ponga a seguirle... tiene que contar con la posibilidad de caer víctima de este malentendido"'k. Y si tales palabras son ajustadas, nos llevan como de la mano al siguiente capítulo.

18. En Concilium 110 (1975) 556. 


\section{Su destino}

El desenlace, con la muerte más terrible de la época, reservada sólo a esclavos y terroristas, es conocido de todos'. También se ha comentado muchas veces la llamativa sobriedad de los evangelios sinópticos al narrar su muerte, lejos de todo tono hagiográfico, martirial o agresivo. $Y$ aún hay que añadir que ese desenlace fue una consecuencia de su vida: Jesús no murió por un designio "metafísico" o expiatorio de Dios, que necesitaba sangre inocente para aplacar su justicia, sino por vivir como había vivido.

Los evangelistas presentan a Jesús anunciando su pasión a los apóstoles, con un lujo de detalles que hacen pensar que tales profecías fueron redactadas por ellos después de los hechos, y retocando confidencias o palabras de Jesús, en las cuales éste les había confiado sus primeros temores. Esas confidencias desataron una reacción en contra por parte de Pedro, apoyada en su idea de lo que tenía que ser el mesías, que sacudió profundamente a Jesús, hasta el extremo de llamarlo Satanás (ver Mc 8, 27-33) 20.

No hablaremos aquí de la cruz, sino de la absoluta soledad que la acompaña. Jesús es crucificado en nombre de Dios, por decisión de las autoridades religiosas, abandonado por sus discípulos (de los cuales, además, uno lo entregó y otro lo negó públicamente), y traicionado por aquellas multitudes que to habían seguido y ahora gritaban "cruciffcale", manipuladas por los poderes de turno". Uno "de fuera" tuvo que ayudarlo a cargar con el madero, porque ya ni podía. Y en torno a su cruz quedaron sólo uno de los discípulos y un grupo de mujeres fieles hasta el final, y más valientes que aquéllos ${ }^{22}$. Los que habían conseguido su muerte, descargados ahora del pavor que le habían tenido, se burlaron de él al pie del cadalso, ofreciéndole un "diálogo" y una buena disposición a escucharlo, si Dios lo bajaba de la cruz.

Ni Dios ni Jesús aceptaron ese chantaje. Pero se comprende que Jesús pasara por momentos de negrura total, que lo hicieron perder pie y sentir (y gritar):

19. Salvo por esa parte de la juventud española a la cual se ha querido negar no ya una formación cristiana (cosa legítima si era voluntad de los padres), sino incluso una información, arrojándolos a un analfabetismo desarraigado y ridículo en este punto.

20. Con dolor hay que añadir que el ejercicio y la figura del ministerio de Pedro en la Iglesia del segundo milenio, se ha parecido demasiado a esa corrección de Pedro a Jesús, que merece la reacción herida de éste: "apárlate de mí, porque tu modo de pensar no es el de Dios".

21. Es inevitable evocar la escena final de aquella excelente película (La lengua de las mariposas), en la que el pueblo vitupera al maestro bueno al que habla querido. movido por el miedo ante el golpe de estado.

22. De modo que, en la medida en que el sacerdocio de Jesús esté constituido por la entrega de su vida, como dice la carta a los Hebreos, cabrla afirmar que casi sólo las mujeres participaron de su sacerdocio. 
"Dios mío ¿por qué me has abandonado?".Y sorprende que, en medio de esa oscura noche. Jesús encontrara fuerzas para asumir su propia muerte, entregando él la vida sin que se la quitaran, y volviendo a clamar: "Abbá, en tus manos pongo mi espíritu". Por eso escribe Jon Sobrino que, si en la primera parte de su vida, Jesús entendió que había de poner al servicio del reino todo aquello que tenía, en la scgunda mitad de su camino comprendió que había de poner al servicio del reino todo aquello que él era. Ese salto desde el abandono de Dios, hasta las manos de un Padre, marca indefectiblemente las profundidades de nucstra historia, a pesar de tantos pesares. La comunidad cristiana posterior entendió que ese salto sólo podía ser obra del Espíritu de Dios (Heb 9. 14). Por eso se comprende tan bien que uno de los militares allí presentes, "al ver cómo había muerlo, bajara del montículo diciendo: realmente, este Hombre era hijo de Dios" (Mc 15, 39).

\section{Conclusión}

El texto anónimo que citábamos al comenzar cste artículo hablaba de la permanencia e influjo de Jesús en la memoria y la historia de la humanidad. Quienes, a través de los sucesos pascuales, acabaron creyendo en él, expresaron esa le conlesando al hombre Jesús como la Presencia y la Impronta de la Divinidad misına en esta historia humana (el "Hijo" de Dios). Por eso, quienes profesan esa fe, están en la obligación de evitar que el culto a la divinidad de Jesús, se convierta en una Torma de escapar a la interpelación de su humanidad. Pues cuando se cae en aquella tentación, no se pierde simplemente algo humanamente valioso, sino a Dios mismo, ya que se desoye una de las enseñanzas [undamenlales del Nuevo Testamenlo: que Jesús "aunque era el Hijo", aprendió en sus propios sufrimientos y en su propia historia humana, que la plenilud del hombre sólo se alcanza en una actitud dialéctica de aceptación y confianza (a la que el Nuevo Testamento llama "obediencia": ver Heb 5, 8-9).

Debernos reconocer que el cristianismo histórico sucumbió con frecuencia a esa tentación, sobre todo desde que aquellos que más tarde se adjudicarían el lítulo de "vicarios de Cristo", accptaron ser proclamados reyes en contra del ejemplo expreso de Jesús. Volver a convertir en piedra angular la memoria subversiva y rechazada de aquel modo de ser humano, es una de las giandes tareas del cristianismo del futuro. Pero eso implicaría que, si el lector comprende ahora y acepta el título de este artículo, se pregunte a continuación qué puede hacer él (sea crcyente o no). para que aquella piedra angular no siga siendo una piedra rechazada por los constructores de este mundo ${ }^{23}$.

23. Para olros aspectos de la posterior fe en Jesús, remito sólo al Cuaderno 26 de "Cristianismo y Justicia" (Cristologia elemental). 


\section{Apéndice. Otros cuatro testimonios de hoy}

\section{Del mundo occidental}

\section{Europa}

Aproximadamente bajo el reinado de Tiberio, nadie sabe cxactamente dónde ni cuándo, un personaje del cual se ignora el nombre, abrió una brecha en el horizonte de los hombres. No fue ciertamente un filósofo, ni tampoco un tribuno, pero debió vivir de tal manera que toda su vida presenta este significado: cada uno de nosotros puede en cualquier instante comenzar un nuevo porvenir.

Decenas, centenas quizá de narradores populares cantaron esta buena noticia. Nosotros conocemos tres o cuatro. El choque que habían experimentado lo expresaron con las mismas imágenes que emplean los pobres, los oprimidos, cuando sucñan que todo se ha vuelto posible: el ciego que empieza a andar, los hambrientos en el desierto que reciben el pan, la prostituta en la que despierta una mujer. el hijo muerto que renace a la vida.

Para hacer llegar hasta el fin cl clamor, él mismo por medio de su resurrección, anunciará que todos los límites, aun la muerte, han sido vencidos.

Algún que otro erudito puede poner en cuestión uno por uno, los hechos de su existencia. A pesar de todo, sin embargo, permanece inmutable esta certeza que transforma la vida. Una hoguera se ha encendido. Luego existió la chispa o la llama primera que prendió, dando nacimiento a la hoguera.

La hoguera la constituyó primariamente un puñado de gente mísera; de no haber sido así, el establishment, desde Nerón a Diocleciano, no les habría maltratado tan duramente.

En este hombre, el amor debió ser militante, subversivo. De no haber sido así no lo habrían crucilicado.

Todas las sabidurías se habían detenido hasta entonces en el destino inexorablc, en la fatalidad. El puso de manifiesto lo absurdo de tales sabidurías. Demostró precisamente lo contrario del destino inexorable: la libertad, la creación, la vida. Arrancó la historia de las garras de la fatalidad.

Con él llegaban a su cumplimiento las promesas de los héroes y de los mártires que acompañaron el gran amanecer de la libertad. No sólo las esperanzas de Isaías o las cóleras de Ezequiel. Prometeo dejaba de estar encadenado. Antígona, enterrada con vida tras los muros, dejaba la tumba. Cadenas y muros, imágenes míticas del destino inexorable, quedaban reducidas a polvo. Todos los ídolos caían muertos y el hombre amanecía. Era como un nuevo nacimiento del hombre. 
Miro esa cruz, que es su símbolo, y sueño en todos los que han ensanchado la brecha... En todos aquellos que nos han hecho tomar conciencia de que el hombre es demasiado grande para bastarse a sí mismo.

Ustedes, los recelosos de la gran esperanza que nos robó Constantino, gentes de Iglesia, ¡devuélvannoslo! También su vida y su muerte son nuestras, de todos aquellos para los que tiene un sentido. De cuantos hemos aprendido de él que el hombre ha sido creado creador... (R. Garaudy, en El Ciervo, 1970, p. 5).

\section{América Latina}

De Jesús impacta la misericordia y la primariedad que le otorga: nada hay más acá ni más allá de ella, y desde ella define la verdad de Dios y del ser humano. De Jesús impacta su honradez con lo real y su voluntad de verdad, su juicio sobre la situación de las mayorías oprimidas y de las minorías opresoras: ser voz de los sin voz y voz contra los que tienen demasiada voz [...] ser defensor de los débiles y denuncia y desenmascaramiento de los opresores. De Jesús impacta su fidelidad para mantener honradez y justicia hasta el final en contra de crisis internas y de persecuciones externas. De Jesús impacla su liberad para hendecir y maldecir, acudir a la sinagoga en sábado y violarlo, libertad, en definitiva, para que nada sea obstáculo para hacer el bien. De Jesús impacta que quiere el fin de las desventuras de los pobres y la felicidad de sus seguidores, y de ahi sus bienaventuranzas. De Jesús impacta que acoja a los pecadores y marginados, que se siente a la mesa con ellos y que se alegre de que Dios se revela a ellos. De Jesús impactan sus signos — sólo modestos signos del reino-. y su horizonte utópico que abarca a toda la sociedad, al mundo y a la historia. Finalmente, de Jesús impacta que confía en un Dios bueno y cercano a quien IJama Padre, y que a la vez está disponible ante un Padre que sigue siendo Dios: misterio inmanipulable.

Ver hecha realidad en una persona cada una de esas cosas, honradez y verdad, misericordia y fidelidad, libertad, gozo y celebración, pequeñez de lo inmediato y grandeza de la utopía, confianza en el Padre y disponibilidad ante Dios es siempre una brisa de aire fresco. Ver gente así es una buena noticia. Pero impacta también, y quizá más que lo anterior, el que en una misma persona aparezcan unidas cosas difícilmente unificables. Jesús es a la vez hombre de misericordia (misereor super turbas) y de denuncia profética ("ay de ustedes, los ricos"), hombre de reciedumbre ("quien quiera venir en pos de mí tome su cruz y sígame") y de delicadeza ("tu fe te ha salvado"), hombre de confianza en Dios ("Abbd", Padre) y de soledad ante Dios ("Dios mío ¿por qué me has abandonado?"). (Jon Sobrino, La fe en Jesucristo. Ensayo desde las víctimas, Madrid, 1999, pp. 309-310). 


\section{De Asia}

\section{India}

[...] Había un hombre que vino al mundo y alimmó ser uno con el Origen: había venido de esa Fuente y debía volver a esa Fuente; en el lapso de tiempo que le fue concedido, pasó su vida haciendo el bien, aunque sin hacer nada preprogramado o realmente fuera de lo ordinario, aunque todo lo que hacía era intenso, completo, auténtico. Sencillamente un hombre que iba por el mundo sin unirse a grupos extremistas, que estaba dispuesto a perdonarlo todo, excepto la hipocresía y, aunque no hiciese discriminación alguna, parecía tomar siempre partido por los desheredados y los oprimidos, y como tal acabó su vida. El vio cl Origen que todo lo origina y sufrió el impacto de las luerzas del mal, pero tuvo una confianza ilimitada en el soplo de ese viento que llamaba Espíritu, que por todas partes penetra, de modo que eso fue lo único que dejo en herencia.

Se vio hombre: Hijo del Hombre ( 82 veces en los evangelios). Le gustaba este nombre, y descubrió para sí mismo y para los demás que su humanidad no cra más que la otra cara de la divinidad, inseparable aunque distinta; tan distinta que fue dolorosamente consciente de la existencia del pecado. $Y, \sin$ embargo, no vio en sí mismo, ni en ningún otro ser humano, el mal, sino el reino de los cielos. Esto es lo que predicó y vivió.

Su nacimiento fue oscuro. Transcurrió buena parte de su vida en la sombra y su muerte fue más oscura todavía. Y sin embargo, nunca sintió ningún tipo de frustración; cuando fue tentado por el poder lo desprecio; y cuando fracasó se alrevió a prometer que iba a cstar realmente presente no sólo mediante el espíriuu, sino también mediante la simple comida y bebida en comunidad. No empleó la violencia y no se dejó intimidar por el poder; predicó el perdón y el amor; pronunció palabras que, según afirmaba, no procedían de él. No elaboró ningún sisterna doctrinal; habló el lenguaje de su tiempo. (Raimon Panikkar, La plenirud del hombre, Barcelona, 1998, pp. 165-166).

\section{China}

Me preocupa con frecuencia la idea de que, en nombre de Jesús, podamos decir o hacer cosas que tienen muy poco que ver con Él. Muchos cristianos cntienden mal la expresión de "Jesús lleno del Espíritu". Jesús no fue "espirilual" en el scntido de "piadoso". De hecho. resultó impío a los ojos de los líderes espirituales de su propia religión [...].

Lo falso del reino de Dios es la promesa vacía hecha por aquellos que poseen privilegios religiosos, y viven desconectados de las necesidades de quienes están fuera del establishment religioso. La verdad del reino de Dios es que pertenece a los desheredados y despreciados [...] Temo que seamos demasiado 
inclinados a crear una imagen de Jesús favorable a nuestros intereses y en la que el mismo Jesús no podría reconocerse[...] Jesús, por la fuerza del Espíritu. I'ranqueó las fronteras que le separaban de los otros, y nos ha revelado cómo él hizo la experiencia de la Verdad y de la Gracia de Dios, por caminos que no había podido experimentar en su propia tradición religiosa. Lo que hace a Jesús radicalmente diverso de los líderes religiosos de su época y lo capacita para ejercer un impacto sin parangón. es su profunda implicación en las realidades hisıóricas de su pueblol...l.

Religión y legalismo han sido muchas veces extraños compañeros que (según una expresión china) "sueñan sueños diferentes en lá misma cama". De csia rcligión legalista quiso Jesús liberar a su pueblo[...].

Cuanto más se arroja a Jesús del centro del poder de las autoridades religiosas, más es alraído hacia las mujeres, los hombres y los niños que, en su comunidad cran excluidos de aquel centro, y también hacia aquellos que se encontraban fuera de su misma comunidad religiosa. Aquellos que según las autoridades religiosas estaban fuera del ámbito de la salvación. Jlegaron a ocupar el lugar central en su iministerio del reino de Dios[...] Dos mil años después. un número cada vez mayor de cristianos en el Tercer mundo, van descubriendo que Jesús. lleno de Gracia y milagro de la Gracia salvadora de Dios, es más grande que los apóstoles y más amplio que el cristianismo. Estamos cayendo en la cuenta de que "dar testimonio de Jesús hasta los confines de la tierra" (Hech I, 8) no significa trasplantar la culiura del occidente cristiano, ni extender su teología o su liturgia. desde el oeste y el norte al oriente y al sur. Significa dar testimonio del modo como Jesús identificaría hoy las manilestaciones de la Gracia salvadora de Dios en el mundo de hoy, y cómo Él se identifica hoy con los varones y mujeres que trabajan y sufren por lo que Él proclamó como "el reino de Dios". (Choan Seng Song, Jesus in the Power of the Spirit, X, XI. pp. 30, 52, $54,56,222,315)$. 